\title{
BLACK-CHINNED HUMMINGBIRD CAPTURED IN WEB OF THE SPIDER NEPHILA CLAVIPES IN MEXICO
}

JOSÉ GILBERTO TORRES-JIMÉNEZ, Tampadhum Asociación Civil para la Conservación de la Vida Silvestre, Calle Prolongación Fuente de Cristal No. 225, Col. Tierra Blanca, San Luis Potosí, 78149, México

R. CARLOS ALMAZÁN-NÚÑEZ, Laboratorio Integral de Fauna Silvestre, Facultad de Ciencias Químico-Biológicas, Universidad Autónoma de Guerrero. Av. Lázaro Cárdenas s/n, Ciudad Universitaria, Chilpancingo, Guerrero, 39000, México; rcarlos. almazan@gmail.com

ANTONIO ESTRADA-RAMÍREZ, Escuela Superior de Ciencias Ambientales, Universidad Autónoma de Guerrero, Campus Llano Largo, Carretera Cayaco-Puerto Márquez s/n, Acapulco, Guerrero, 39906, México

On 9 October 2011 at approximately 14:00 hours, we observed a female Blackchinned Hummingbird (Archilochus alexandri) caught in the web of a Golden Silk Spider (Nephila clavipes), $2 \mathrm{~km}$ from the Media Luna wellspring ( $21^{\circ} 52^{\prime} 55^{\prime \prime} \mathrm{N}$; $100^{\circ} 02^{\prime} 27^{\prime \prime} \mathrm{W}$, elevation $1005 \mathrm{~m}$ ) in a protected natural area in the Sierra Madre Oriental of San Luis Potosí in central-eastern Mexico. The web was in a willow tree (Salix sp.) within secondary successional forest surrounded by farmland. The event was discovered opportunistically over five days of observing birds at the site.

We observed the hummingbird for approximately 40 minutes as it attempted to break free from the web. On one occasion the spider approached the hummingbird within approximately $30 \mathrm{~cm}$ but did not show interest in contact. Toward the end of our observation, the hummingbird showed signs of exhaustion and weakness and died in the web. We stayed 15 minutes after the hummingbird died but did not observe any behavior by the spider that would suggest it was attempting to consume or attack the hummingbird.

This is the first record of a Black-chinned Hummingbird captured in the web of a Golden Silk Spider and only the second report of any hummingbird being caught in a web of this species in Mexico (Martínez-Sánchez et al. 2013). Since we observed no attempt at predation by the spider, we consider this capture to be accidental. This is consistent with most records of birds captured in Golden Silk Spider webs, including hummingbirds and some passerines (Teixeira et al. 1991, Duca and Modesto 2007, Sakai 2007, Martínez-Sánchez et al. 2013). Nevertheless, there are several cases of birds wrapped in silk (Brooks et al. 2008, Brooks 2012), including a documented attack on a Double-collared Seedeater (Sporophila caerulescens) by a Golden Silk Spider in Brazil (Teixeira et al. 1991).

Because of the size and strength of its webs, capture of birds may be common in habitats the Golden Silk Spider occupies (Brooks 2012, Rodriguez et al. 2015). These spider webs may trap small hummingbirds such as the Black-chinned, but this type of accidental mortality is better documented for other small vertebrates such as amphibians and reptiles (Gallon 2000) and tarantulas of the family Theraphosidae (Teixeira et al. 1991).

Several hypotheses concerning the capture of birds in spider webs have emerged (Brooks 2012). For example, Graham (1997) suggested the unlikelihood of birds being preyed upon by spiders because of their size, but the possibility remains that other predators may remove birds from the webs. Even if birds are able to free themselves, they could remain susceptible to predation because of exhaustion. Sakai (2007) hypothesized that Long-billed Hermits (Phaethornis longirostris) learn to avoid spider webs when flying through forests, but birds may not notice webs in unfamiliar territory. 


\section{NOTES}

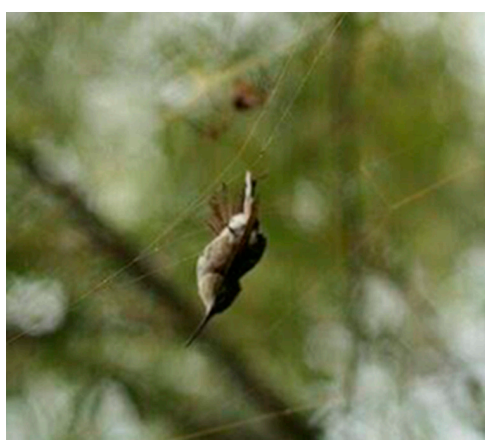

Figure 1. Black-chinned Hummingbird trapped in a web of Nephila clavipes in central-eastern Mexico, 9 October 2011. The spider is visible in the background of the photograph.

Photo by José Gilberto Torres-Jiménez

At this site we observed additional hummingbird species, such as the Ruby-throated (Archilochus colubris), and there was an abundance of Golden Silk Spiders, so such captures may be more numerous than currently thought. The extent to which events of this nature occur remains unknown, but each observation adds to the understanding of interactions among spiders and hummingbirds.

We thank Paulina Solis for confirming the spider's identification. Coro Arizmendi and Luis Sánchez-González also confirmed the hummingbird's identification. William Baltosser and Andrew B. Johnson made comments that improved the original manuscript.

\section{LITERATURE CITED}

Brooks, D. M. 2012. Birds caught in spider webs: A synthesis of patterns. Wilson J. Ornithol. 124:345-353; doi 10.1676/11-148.1.

Brooks, D. M., Burkett, W., and Sarkozi, D. L. 2008. Swainson's Thrush (Catharus ustulatus) caught in web of golden silk orb weaver (Nephila clavipes). Bull. Tex. Ornithol. Soc. 41:27.

Duca, C., and Modesto, W. 2007. Spider web as a natural trap for small birds. Rev. Bras. Ornitol. 15:615-616.

Gallon, R. C. 2000. The Natural History of Tarantula Spiders. Br. Tarantula Soc., London.

Graham, D. L. 1997. Spider webs and windows as potentially important sources of hummingbird mortality. J. Field Ornithol. 68:98-101.

Martínez-Sánchez, I., Niño, S., and Valencia-Herverth, J. 2013. Primer reporte para México del colibrí Archilochus colubris atrapado en una telaraña de Nephila clavipes. Huitzil 14:110-112.

Rodríguez, R. L., Briceño, R. D., Briceno-Aguilar, E., and Höbel, G. 2015. Nephila clavipes spiders (Araneae: Nephilidae) keep track of captured prey counts: Testing for a sense of numerosity in an orb-weaver. Anim. Cogn. 18:307-314; doi 10.1007/s10071-014-0801-9.

Sakai, W. H. 2007. Long-billed Hermit (Phaetornis superciliosus) caught in golden orb-spider (Nephila clavipes) web. Ornitol. Neotrop. 18:117-119.

Teixeira, D. M., Luigi, G., and Schloemp, I. M. 1991. Aves brasileiras como presas de artrópodes. Ararajuba 2:69-74. 